\title{
Convergent Excitation of Dorsal Raphe Serotonin Neurons by Multiple Arousal Systems (Orexin/Hypocretin, Histamine and Noradrenaline)
}

\author{
Ritchie E. Brown, Olga A. Sergeeva, Krister S. Eriksson, and Helmut L. Haas \\ Institut für Neurophysiologie, Heinrich-Heine-Universität, D-40001 Düsseldorf, Germany
}

Dorsal raphe serotonin neurons fire tonically at a low rate during waking. In vitro, however, they are not spontaneously active, indicating that afferent inputs are necessary for tonic firing. Agonists of three arousal-related systems impinging on the dorsal raphe (orexin/hypocretin, histamine and the noradrenaline systems) caused an inward current and increase in current noise in whole-cell patch-clamp recordings from these neurons in brain slices. The inward current induced by all three agonists was significantly reduced in extracellular solution containing reduced sodium $(25.6 \mathrm{~mm})$. In extracellular recordings, all three agonists increased the firing rate of serotonin neurons; the excitatory effects of histamine and orexin A were occluded by previous application of phenylephrine, suggesting that all three systems act via common effector mechanisms.

The dose-response curve for orexin B suggested an effect mediated by type II $\left(\mathrm{OX}_{2}\right)$ receptors. Single-cell PCR demon- strated the presence of both $\mathrm{OX}_{1}$ and $\mathrm{OX}_{2}$ receptors in tryptophan hydroxylase-positive neurons. The effects of histamine and the adrenoceptor agonist, phenylephrine, were blocked by antagonists of histamine $\mathrm{H}_{1}$ and $\alpha_{1}$ receptors, respectively. The inward current induced by orexin $A$ and phenylephrine was not blocked by protein kinase inhibitors or by thapsigargin.

Three types of current-voltage responses were induced by all three agonists but in no case did the current reverse at the potassium equilibrium potential. Instead, in many cases the orexin A-induced current reversed in calcium-free medium at a value $(-23 \mathrm{mV})$ consistent with the activation of a mixed cation channel (with relative permeabilities for sodium and potassium of 0.43 and 1 , respectively).

Key words: arousal; narcolepsy; tuberomammillary; voltage clamp; orexin; dorsal raphe
The activity of the brain during waking is maintained by the concerted action of a number of neuromodulators. These substances are released from diff use activating systems located in the brain stem (serotonin and noradrenaline), hypothalamus (histamine and orexins), and basal forebrain (acetylcholine) (McCormick, 1992; Kilduff and Peyron, 2000; Lin, 2000). One of the important neuromodulators involved in the control of waking physiology is the monoamine, serotonin (5-HT). Serotonin cooperates with acetylcholine and other amines during waking to cause desynchronization of the cortex (Dringenberg and Vanderwolf, 1998). Behavioral experiments and clinical findings have shown that an adequate level of serotonergic tone is essential for normal brain function. Hypof unction of this system leads to a loss of "behavioral control" and psychiatric problems such as excessive aggressiveness, eating disorders, and suicide (Lucki, 1998).

The serotonergic innervation of the forebrain originates primarily in the dorsal raphe nucleus of the brainstem (Jacobs and Azmitia, 1992). Like noradrenaline neurons in the locus coeruleus (Aston-Jones and Bloom, 1981) and histamine neurons in the tuberomammillary nucleus (Sakai et al., 1990), most of the serotonin neurons in the dorsal raphe fire tonically at a slow rate during waking, fire considerably less during slow-wave sleep, and cease firing during rapid eye movement (REM) sleep (Trulson and Jacobs, 1979; Jacobs and Fornal, 1991; Sakai and Crochet,

Received Nov. 7, 2001; revised July 15, 2002; accepted July 31, 2002.

Correspondence should be addressed to Dr. Ritchie Brown, Department of Psychiatry, Harvard Medical School, Brockton Veterans Administration Hospital, Research 151 C, 940 Belmont Street, Brockton, MA, 02301. E-mail: Ritchie_Brown@hms. harvard.edu.

Copyright (C) 2002 Society for Neuroscience $\quad 0270-6474 / 02 / 228850-\bullet \$ 15.00 / 0$
2001). In contrast to the in vivo situation, most serotonin neurons do not fire spontaneously in vitro (Vandermaelen and Aghajanian, 1983). Much evidence supports a role for the noradrenergic system in maintaining tonic firing of serotonin neurons. Systemic or local administration of $\alpha_{1}$-adrenoceptor antagonists reduces 5-HT neuron firing in vivo (Baraban and Aghajanian, 1980), whereas bath application of the $\alpha_{1}$-adrenoceptor agonist, phenylephrine, restores tonic firing in vitro (Vandermaelen and Aghajanian, 1983).

In comparison with noradrenaline, little is known about how other arousal systems affect the firing of serotonin neurons. Recently we have shown that orexin A strongly excites dorsal raphe serotonin neurons (Brown et al., 2001a). Orexin neurons are located in the lateral hypothalamus and project particularly strongly to arousal-related systems such as the dorsal raphe (Chemelli et al., 1999; Date et al., 1999). C-fos expression in orexin neurons and preproorexin mRNA levels show circadian variations, with the strongest expression being observed during waking (Taheri et al., 2000; Estabrooke et al., 2001), whereas intracerebroventricular application of orexin A potently enhances arousal (Piper et al., 2000). On the other hand, destruction of orexin neurons or disruption of the orexin type II receptor causes the sleep disorder narcolepsy, the symptoms of which include excessive daytime sleepiness and disrupted nighttime sleep (Lin et al., 1999; Thannickal et al., 2000).

While investigating the effects of orexins on dorsal raphe neurons, it became apparent that there were considerable similarities between the effects of orexins and $\alpha_{1}$ receptor agonists on 5-HT neurons. Here we show that the orexin system, the noradrenaline system, and a third arousal-related system, the histamine system 
(Lin, 2000; Brown et al., 2001b), converge on common ionic mechanisms to excite dorsal raphe serotonin neurons.

\section{MATERIALS AND METHODS}

Preparation and maintenance of slices. Brain slices were prepared from 2to 4-week-old male Wistar rats. All experiments were conducted in compliance with German law and with the approval of the Bezirksregierung Düsseldorf. The animals were quickly decapitated, and the brains were transferred to a modified artificial CSF (ACSF) containing (in mM): sucrose $209, \mathrm{KCl} 1.8, \mathrm{KH}_{2} \mathrm{PO}_{4} 1.2, \mathrm{MgSO}_{4} 1.3, \mathrm{CaCl}_{2} 2$, $\mathrm{NaHCO}_{3}$ 25.6, D-glucose $10\left(\mathrm{pH} 7.4\right.$ when bubbled with $95 \% \mathrm{O}_{2} / 5 \%$ $\mathrm{CO}_{2}, 300 \mathrm{mOsm}$ ) (Aghajanian and Rasmussen, 1989). Three 400- $\mu \mathrm{m}-$ thick coronal brain slices were cut from anterior-posterior level -8.1 to -9.3 with respect to bregma, according to the atlas of Kruger et al. (1995), using a Vibratome (TPI, St. Louis, MO). Subsequently, the ventral portions of the slices were removed, and they were transferred to a holding chamber filled with standard ACSF containing (in $\mathrm{mM}$ ): $\mathrm{NaCl}$ 124, $\mathrm{KCl} 1.8, \mathrm{KH}_{2} \mathrm{PO}_{4} 1.2, \mathrm{MgSO}_{4} 1.3, \mathrm{CaCl}_{2} 2, \mathrm{NaHCO}_{3}$ 25.6, D-glucose 10 (pH 7.4 when bubbled with $\left.95 \% \mathrm{O}_{2} / 5 \% \mathrm{CO}_{2}, 295 \mathrm{mOsm}\right)$. Slices remained in the holding chamber at room temperature until use, when they were transferred individually to a recording chamber (submergedtype) and perfused with ACSF at a flow rate of $3 \mathrm{ml} / \mathrm{min}$. Recordings were made at $31^{\circ} \mathrm{C}$.

Electrophysiological recordings. Extracellular single-unit recordings were made from serotonergic neurons using glass pipettes filled with ACSF (12-20 M $\Omega$ ). Signals were recorded using an Axoclamp 2B amplifier (Axon Instruments, Foster City, CA), filtered at $0.1-10 \mathrm{kHz}$, sampled at $20 \mathrm{kHz}$, and analyzed with pClamp8 software (Axon Instruments). The frequency of extracellular action potentials was determined on-line in bins of $15 \mathrm{sec}$ duration. The $\alpha_{1}$ adrenoceptor agonist, phenylephrine $(3 \mu \mathrm{M})$, was added to the perfusion solution to enhance the number of spontaneously active serotonin neurons (Vandermaelen and Aghajanian, 1983). Under these conditions cells were considered to be serotonergic if (1) their firing rate was below $3.5 \mathrm{~Hz}$, (2) the waveform of extracellularly recorded action potentials exhibited a large initial positivity followed by a smaller multiphasic tail with a total waveform duration $>3 \mathrm{msec}$, (3) their firing was reduced by $>50 \%$ by application of the $5-\mathrm{HT}_{1 \mathrm{~A}}$ agonist 8-OH-DPAT (100 nM), removal of phenylephrine from the bath, or application of the $\alpha_{1}$ adrenoceptor antagonist, prasozin $(1 \mu \mathrm{M})$. Non-serotonergic neurons were encountered only infrequently with phenylephrine in the bath. They fired at faster rates $(>5 \mathrm{~Hz})$, had biphasic action potentials of shorter duration, were unaffected by application of 8-hydroxy-2-dipropylaminotetralin hydrobromide (8-OHDPAT), and were only weakly affected by removal of phenylephrine from the bath.

Intracellular recordings were made from neurons in the nucleus dorsalis raphe using the "blind" whole-cell patch-clamp technique (Staley et al., 1992). Patch pipettes (3-6 M $\Omega$ ) were pulled from borosilicate glass (GB150F-8P, Science Products, Hofheim, Germany) and filled with an intracellular solution containing (in $\mathrm{mM}$ ): potassium gluconate $135, \mathrm{NaCl}$ 5, $\mathrm{MgCl}_{2}$ 2, HEPES 10, EGTA 0.1, $\mathrm{Na}_{2}$ ATP 2, NaGTP 0.5 (pH 7.25 with
$\mathrm{KOH}, 275 \mathrm{mOsm})$. Intracellular signals were recorded using an Axoclamp 2B amplifier (Axon Instruments) in bridge mode or in the continuous, single-electrode, voltage-clamp mode. Serotonergic neurons were identified by their characteristic electrophysiological properties as described previously (Brown et al., 2001a). Membrane potential measurements were adjusted for a $-15 \mathrm{mV}$ liquid junction potential between pipette solution and bath solution (calculated using pClamp8 software; Axon Instruments). Series resistance varied from 6 to $40 \mathrm{M} \Omega$; the bridge balance was maintained continuously and monitored during currentclamp experiments. Long, hyperpolarizing steps $(-25$ or $-50 \mathrm{pA}, 500$ $\mathrm{msec}$ ) were applied every $30 \mathrm{sec}$ to monitor the input resistance. Recordings were low-pass filtered at $10 \mathrm{kHz}$.

Voltage-clamp recordings were made only from neurons having a stable series resistance of $<20 \mathrm{M} \Omega$. Series resistance compensation was not used. Tetrodotoxin (TTX; $0.5 \mu \mathrm{M}), 6$-cyano-7-nitroquinoxaline-2,3 dione (CNQX; $5 \mu \mathrm{M})$, D-2-aminophosphonopentanoic acid (AP5; 50 $\mu \mathrm{M})$, and bicuculline methiodide $(10 \mu \mathrm{M})$ were added to the bathing solution to block voltage-gated sodium channels and spontaneous synaptic potentials mediated by glutamate AMPA and NMDA receptors and $\mathrm{GABA}_{\mathrm{A}}$ receptors, respectively. Long $(4 \mathrm{sec})$ voltage ramps from -75 to $-130 \mathrm{mV}$ were applied every $30 \mathrm{sec}$. Current-responses were sampled at $2 \mathrm{kHz}$ and low-pass filtered at $1 \mathrm{kHz}$. In $0 \mathrm{Ca}^{2+} / 3.3 \mathrm{Mg}^{2+}$-containing solution, longer $(20 \mathrm{sec})$ ramps from -100 to $+20 \mathrm{mV}$ were applied every $40 \mathrm{sec}$ and sampled at $200 \mathrm{~Hz}$. Continuous recordings of membrane voltage or current were made using a Gould TA550 chart recorder (Gould Electronics, Cleveland, $\mathrm{OH}$ ).

Cellular RNA harvest and reverse transcriptase-PCR. For preparation of isolated cells, the nucleus dorsalis raphe was dissected from the slice and incubated with papain (Sigma, Deisenhofen, Germany) in crude form $(0.3-0.5 \mathrm{mg} / \mathrm{ml})$ for $40 \mathrm{~min}$ at $37^{\circ} \mathrm{C}$. Subsequently the tissue was placed in a bathing solution of the following composition (in $\mathrm{mM}$ ): $\mathrm{NaCl} 150$, $\mathrm{KCl} 3.7, \mathrm{CaCl}_{2} 2.0, \mathrm{MgCl}_{2}$ 2.0, HEPES 10, $\mathrm{pH}$ 7.4. Cells were separated by gentle pipetting. Neurons visually selected on an inverted microscope were digitally photographed and approached with a patch electrode, and a gigaohm seal was obtained. The thick-walled borosilicate glass electrodes had resistances of 2-5 $\mathrm{M} \Omega$ after filling with the following solution containing (in mM): $\mathrm{CsCl} 140, \mathrm{MgCl}_{2} 2, \mathrm{CaCl}_{2} 0.5$, EGTA 5, HEPES/ $\mathrm{CsOH} 10$ (sterilized by autoclaving and adjusted to $\mathrm{pH}$ 7.2). The cells were voltage clamped by an EPC-9 amplifier (HEKA Electronics, Lambrecht, Germany) at $-70 \mathrm{mV}$. After the whole-cell configuration was established, the electrode with the patched neuron was lifted into the application system where the cytoplasm was sucked into the electrode. Cell identification was verified by reverse transcriptase (RT)-PCR analysis of tryptophan hydroxylase (Tph) expression. The protocols of the RT reaction and PCR amplification were similar to those described previously (Vorobjev et al., 2000). The primers designed to recognize Tph and orexin (hypocretin) receptor cDNAs are listed in Table 1 . The thinwalled PCR tubes contained a mixture of first-strand cDNA template $(2-5 \mu \mathrm{l}), 10 \times$ PCR buffer $(5 \mu \mathrm{l}), 10 \mathrm{pM}$ each of sense and antisense primer, and $200 \mu \mathrm{M}$ each of deoxyNTP (dNTP) and $2.5 \mathrm{U}$ Taq polymerase. The final reaction volume was adjusted to $50 \mu \mathrm{l}$ with nuclease-free

Table 1. Primers used in single-cell PCR experiments

CDNA

Primers

GenBank access no./size of the product

Tph
Up1 ${ }^{a}$
Lo1,2
Up2
OX $_{1}$
Up1
Lo1
Up2
Lo2
OX
Up1,2
Lo1
Lo2

5'-GTG GAG TTT GGA CTG TGC AA-3'
5'-TCA CAC ACT GGG CCA CCT G-3'
5'-TGA GAG TCT TTG GTG CCG G-3'

5'-CTG GC(AT) GAT GTG CT(GT) GTG AC-3'

5'-AAC AGC AGA GGG TGG CAG AT-3'

5'-TGT TAG TGG ACA TCA CCG AAT C-3'

5'-TGA AGC TGA GAG TCA GCA CTG-3'

5'-CTG GC(AT) GAT GTG CT(GT) GTG AC-3'

5'-TGG CTG TGC TCT TGA ACA TC-3'

5'-GGC AAT GCA GCT CAA TGT AA-3'
X53501

$356 b p$

AF041244

$108 \mathrm{bp}$

AF041246

$156 b p$

${ }^{a}$ Numbers indicate round of amplification when the primers were used. 
water (Promega). The $\mathrm{Mg}^{2+}$ concentration was $1.5 \mathrm{~mm}$ for all reactions. The Taq enzyme, PCR buffer, $\mathrm{Mg}^{2+}$ solution, and four dNTPs were all purchased from Qiagen (Erkrath, Germany). All oligonucleotides were synthesized by MWG-Biotech (Ebersberg, Germany), and amplification was performed on a thermal cycler (GenAmp 9600, Perkin-Elmer, Weiterstadt, Germany). A two-round amplification strategy was used in each protocol. In each round, 35 cycles of the following thermal programs were used: denaturation at $94^{\circ} \mathrm{C}$ for $48 \mathrm{sec}$, annealing at $53^{\circ} \mathrm{C}$ for $1 \mathrm{~min}$, and extension at $72^{\circ} \mathrm{C}$ for $90 \mathrm{sec}$. For the second amplification round, $1 \mu \mathrm{l}$ of the product from the first amplification was used as a template.

The results of amplification were analyzed by agarose gel $(2 \%)$ electrophoresis and staining with ethidium bromide. All products of the second round of amplification were purified (PCR purification kit from Qiagen) in water and subjected to sequencing in both directions (which was done on an automatic sequencer; model 377, ABI, Weiterstadt, Germany). Sequencing of the amplification products revealed their identity with the known rat cDNA sequences (see GenBank access numbers in Table 1).

Drugs and statistics. Bicuculline methiodide, chelerythrine chloride, CNQX, ethylene glycol-bis ( $\beta$-aminoethyl ether) EGTA, HEPES, histamine dihydrochloride, $\mathrm{Na}_{2} \mathrm{ATP}, \mathrm{NaGTP}, \mathrm{NiCl}_{2}, \mathrm{~N}$-methyl-D-glucamine (NMDG), phenylephrine hydrochloride, potassium gluconate, and pyrilamine (mepyramine) maleate were obtained from Sigma; 8-OH-DPAT, AP5, $(9 R, 10 S, 12 S)-2,3,9,10,11,12$-hexahydro-10-hydroxy-9-methyl-1-oxo9,12-epoxy-1H-diindolo[1,2,3-fg:3', 2', $1^{\prime}$-k1]pyrrolo[3,4-1][1,6]benzodiazocine-10-carboxylic acid, hexyl ester (KT5720), phorbol 12-myristate 13acetate, 2-(2-amino-3-methoxyphenyl)-4H-1-benzopyran-4-one (PD98059), prasozin hydrochloride, and thapsigargin were from Tocris Cookson (Bristol, UK) and tetrodotoxin citrate was from Alomone Laboratories (Jerusalem, Israel). Orexin A and B peptides and melanin concentrating hormone (Bachem) were dissolved in $0.9 \%$ saline to a concentration of $10 \mu \mathrm{M}$, and the resulting solution was stored as frozen aliquots at $-20^{\circ} \mathrm{C}$. CNQX, KT5720, PD98059, and thapsigargin were dissolved in dimethylsulfoxide (final bath concentration $<0.1 \%$ ). Other drugs were dissolved in distilled water and stored as stock solutions $(100$ or $1000 \times$ final concentrations) at $4^{\circ} \mathrm{C}$. Drugs were bath applied.

All values are given as the mean \pm SEM. Statistical comparisons were made using the unpaired or paired Student's $t$ test, as appropriate.

\section{RESULTS}

\section{Responses of serotonergic cells to orexins in current clamp}

As we have reported previously (Brown et al., 2001a), bath application of low concentrations (5-300 nM) of orexin A depolarized serotonergic cells and elicited sodium-dependent action potentials $(n=36)$. In the presence of the selective voltagedependent sodium channel blocker TTX $(0.5 \mu \mathrm{M})$, orexin A still depolarized serotonin neurons; in some neurons ( 6 of 13 neurons tested with 100 or $300 \mathrm{~nm}$ orexin A), high-amplitude calciumdependent action potentials were observed. These calciumdependent action potentials were broader than TTX-sensitive action potentials and could be blocked by the addition of cadmium $(100 \mu \mathrm{M})$ to the bathing medium. Application of $100 \mathrm{~nm}$ orexin A led to a depolarization of $8.7 \pm 1.3 \mathrm{mV}(n=8)$. A higher concentration of orexin A (300 nM) did not lead to a larger effect $(9.2 \pm 1.4 \mathrm{mV} ; n=5)$, so this concentration was used as standard in subsequent experiments. Washout was slow; complete reversal of the effect often required at least $1 \mathrm{hr}$.

In three of six cells, when the membrane potential was manually clamped at the pre-drug level during the orexin A-induced depolarization, an increase in the voltage responses to hyperpolarizing current steps could be observed, i.e., the input resistance was increased (to $127 \pm 9 \%$ of control) (Fig. 1A(i)). However, the magnitude of this effect was variable, and large depolarizations could also be observed without significant changes in input resistance (Fig. 1A(ii)). On average, in the presence of TTX, $100 \mathrm{nM}$ orexin A caused an increase in the input resistance to $112 \pm 8 \%$ of control $(n=6)$.

Although orexin A activates both orexin receptors with a
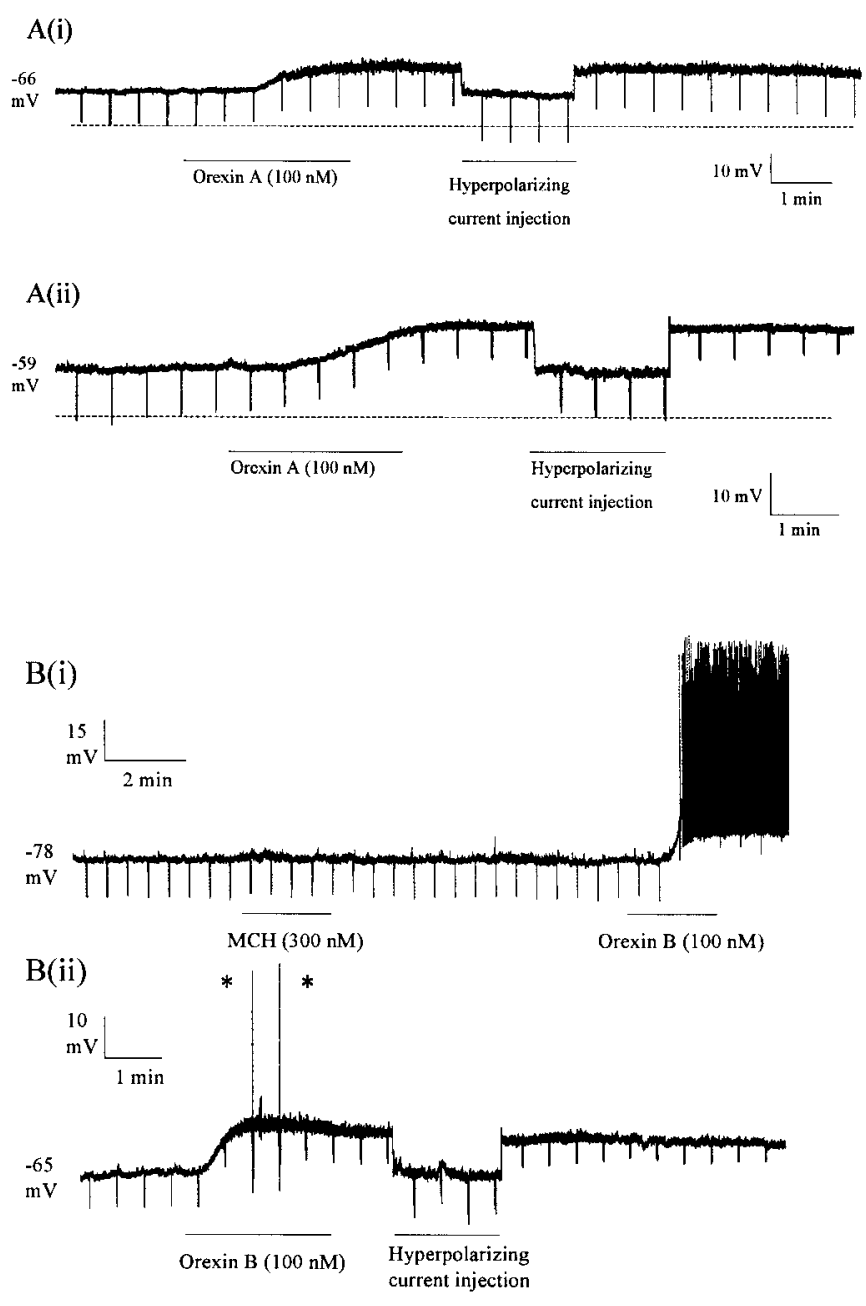

Figure 1. Responses to orexins under current clamp. A, Input resistance changes in serotonin neurons in response to orexin A. Chart recordings of membrane potential are shown. Downward deflections are from hyperpolarizing pulses $(-50 \mathrm{pA}, 500 \mathrm{msec})$ used to test the input resistance. Bath application of orexin A (100 nM, $3 \mathrm{~min})$ led to an increase in the input resistance of the neuron in (i) but not that shown in (ii). $B$, Orexin $\mathrm{B}$ excites serotonin neurons. Chart recordings of membrane potential are shown. Downward deflections are from hyperpolarizing pulses $(-25 \mathrm{pA}$, $500 \mathrm{msec}$ ) used to test the input resistance. $B(i)$, Melanin concentrating hormone $(M C H)$ does not affect the membrane potential, whereas in the same cell orexin B causes a large depolarization and elicits tetrodotoxinsensitive action potentials. $B($ ii), In a different cell, in the presence of tetrodotoxin $(0.5 \mu \mathrm{M})$, orexin B causes a large depolarization and the appearance of high-amplitude calcium spikes (asterisks) at the end of hyperpolarizing current pulses.

similar affinity, orexin B is a relatively selective agonist for the type II orexin receptor (Sakurai et al., 1998). Bath application of orexin B caused a similar response as orexin A, i.e., it depolarized the serotonin neurons and caused the appearance of action potentials (Fig. $1 B(i)$ ). In the presence of TTX, $100 \mathrm{~nm}$ orexin B caused a depolarization in all cells tested, the magnitude of which $(9.3 \pm 1.4 \mathrm{mV} ; n=8)($ Fig. $1 B(i i))$ was not significantly different from that caused by $100 \mathrm{~nm}$ orexin A. Changes in input resistance were variable, as was the case with orexin A. On average, $100 \mathrm{~nm}$ orexin B increased the input resistance to $119 \pm 7 \%$ of control $(n=8)$. In contrast to the effects of orexin A and B, another peptide neurotransmitter produced in the lateral hypothalamus, melanin-concentrating hormone $(\mathrm{MCH})$, had only minor effects 

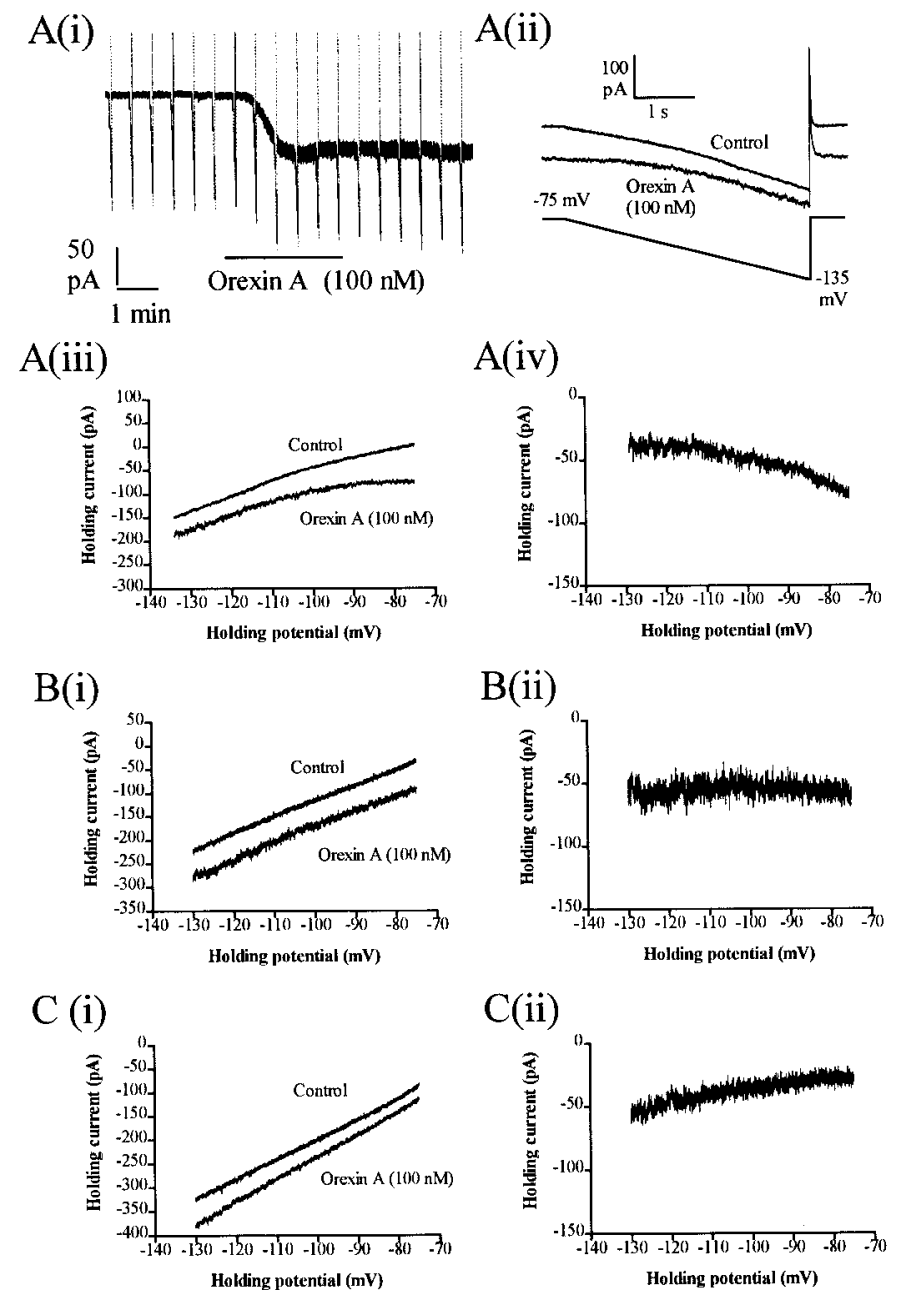

Figure 2. Orexin A causes an inward current under voltage clamp. $A(i)$, Chart recording of holding current. Downward deflections represent the responses to voltage ramps from the holding potential of -75 to $-130 \mathrm{mV}$ (illustrated in $A(i i))$. Orexin A (100 nM) causes an inward current and an increase in current noise. In $A$ (iii) the voltage ramps have been converted to a current-voltage plot. In $A(i v)$ the control current responses have been subtracted from the responses in the presence of orexin A. In this cell the net orexin A-induced current declines in amplitude in the hyperpolarizing direction. $B$ and $C$ show the responses in two other serotonin neurons. In $B$ the orexin A-induced current is voltage independent in the range -75 to $-130 \mathrm{mV}$, whereas in $C$ the current declines in amplitude in the depolarizing direction.

on the membrane potential of serotonin neurons (Fig. 1B(i)) $(1.3 \pm 0.7 \mathrm{mV} ; n=6)$.

\section{Responses of serotonergic cells to orexins under voltage clamp}

In voltage-clamp experiments, cells were held at $-75 \mathrm{mV}$, and slow voltage ramps from -75 to $-130 \mathrm{mV}$ were applied every 30 sec (Fig. 2). Bath application of orexin A (100 nM) led to the appearance of an inward current that was associated with a large increase in channel noise (Fig. $2 A$ ). On average, the inward current at $-75 \mathrm{mV}$ amounted to $-44.1 \pm 4.0 \mathrm{pA}(n=7)$. Voltage ramps in the absence and presence of orexin A (Fig. $2 B$ ) were converted to current-voltage $(I-V)$ plots. Because orexin A increased input resistance under current-clamp conditions, we expected to observe that the $I-V$ plots would cross at the potassium equilibrium potential. However, this was not observed in any experiment with orexin A. Three types of responses were observed. In three of seven cases we observed that the curves converged from -75 to $-100 \mathrm{mV}$ but remained parallel thereafter (type A response) (Fig. 2A(iii)); in two of seven cases the curves remained parallel over the entire voltage range tested (type B response) (Fig. 2B); in the remaining two cases the curves converged as the voltages became more positive (type $\mathrm{C}$ response) (Fig. 2C). In contrast to the results obtained with orexin A, application of the selective $5-\mathrm{HT}_{1 \mathrm{~A}}$ receptor agonist, 8-OHDPAT, which is known to activate an inwardly rectifying potassium conductance in these neurons (Aghajanian and Lakoski, 1984; Penington et al., 1993), caused an outward current of $67 \pm$ $19 \mathrm{pA}(n=4) . I-V$ curves in control and in the presence of 8-OH-DPAT crossed at $-101.1 \pm 1.4 \mathrm{mV}(n=4)$, which was near the calculated potassium equilibrium potential $(-99.5 \mathrm{mV})$.

Application of orexin B under voltage clamp led to essentially identical responses as seen with orexin A (Fig. $3 A$ ), i.e., an inward current with increased noise, with a current-voltage relationship that did not cross at the potassium equilibrium potential (Fig. $3 A(i i))$. At $100 \mathrm{~nm}$, orexin $\mathrm{B}$ induced an inward current of $-57.2 \pm 8.1 \mathrm{pA}(n=7)$, which was not significantly stronger than that of orexin A $(p=0.17)$. The effect of orexin B was dose dependent, with higher concentrations giving larger inward currents; the $\mathrm{EC}_{50}$ was $22 \mathrm{~nm}$ (Fig. $3 A$ (iii)). In 2 of 18 neurons tested with high $(\geq 100 \mathrm{~nm}$ ) concentrations of orexin $\mathrm{B}$, there was no response, although these neurons subsequently responded to orexin A (100 nM) or phenylephrine ( $3 \mu \mathrm{M}$; see below) indicating that some neurons may lack type II receptors. Taking together the current-voltage responses of all experiments with high concentrations of orexin B $(100,300$, or $600 \mathrm{~nm})$, there were three type A responses, eight type $B$ responses, and four type $C$ responses.

The fact that orexin B was similarly effective as orexin A in exciting serotonin neurons at low concentrations suggested a role for the orexin type II receptor. Because pharmacological tools for investigating orexin receptors are not available at the current time, we took an alternative approach and determined the expression of orexin receptors in neurons acutely isolated from the dorsal raphe region.

\section{Single-cell PCR for orexin receptors}

Serotonin neurons were identified by the presence of signal for Tph. The Tph-positive neurons (14 of 22) had somata $20-30 \mu \mathrm{m}$ in diameter with polygonal to round shapes and several dendrites. Some neurons from the dorsal raphe region that were collected for the single-cell PCR study turned out to be Tph negative ( 8 of $22)$; these neurons were similar in size and shape to the Tphpositive neurons and were not investigated further. We cannot exclude the possibility that these neurons also express Tph, but below our detection level; another possibility is that they are GABAergic interneurons. In the amplifications with orexin receptor-specific primers, the obtained amplimers had the expected sizes of 108 and 156 bp for $\mathrm{OX}_{1}$ and $\mathrm{OX}_{2}$, respectively. Genomic DNA amplification products with our primers would have the expected sizes of $605 \mathrm{bp}\left(\mathrm{OX}_{1}\right)$ and $653 \mathrm{bp}\left(\mathrm{OX}_{2}\right)$, but these products were never seen on the stained gels.

The majority of the Tph-positive neurons, 9 of 14, expressed both types of orexin receptors, whereas 5 cells expressed only $\mathrm{OX}_{1}$ (Fig. 3B). Although we did not do a detailed quantification, we could observe that the signal for $\mathrm{OX}_{1}$ was generally strong, whereas the $\mathrm{OX}_{2}$ signal was more variable in strength and usually weaker. 


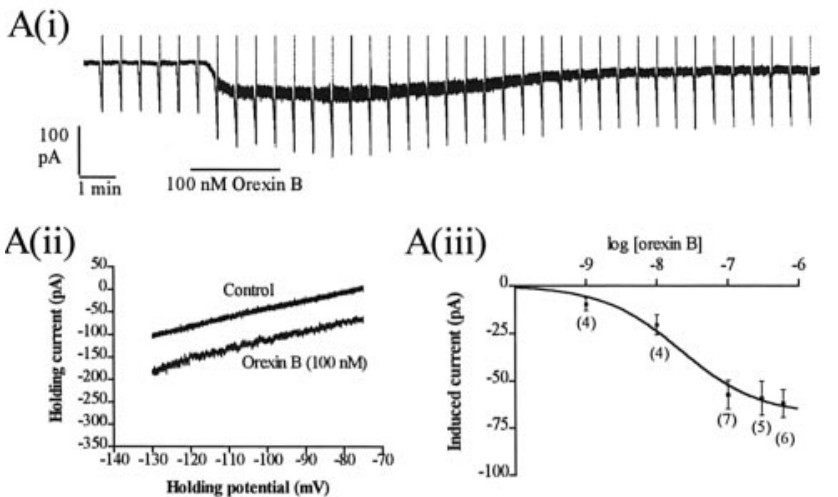

B

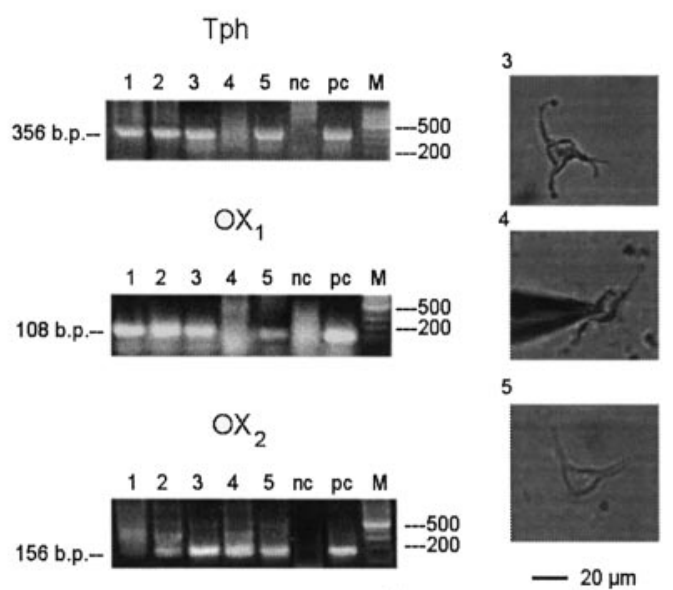

Figure 3. Orexin receptors involved in the excitation of dorsal raphe neurons. $A$, Orexin $\mathrm{B}$ induces an inward current and increase in current noise under voltage clamp. $A(i)$, Chart recording of holding current. Downward deflections represent the responses to voltage ramps from the holding potential of -75 to $-130 \mathrm{mV}$. A(ii), The voltage ramps have been converted to current-voltage plots in control and in the presence of orexin B. A(iii), Dose-response relationship for the orexin B-induced inward current indicates that the $\mathrm{OX}_{2}$ receptor is involved. $B$, Representative results from the single-cell RT-PCR study. Dissociated neurons were tested for the expression of tryptophan hydroxylase $(T p h)$ and with primers for both orexin receptors $\left(O X_{1}\right.$ and $\left.O X_{2}\right)$. Most Tph-positive neurons expressed both orexin receptors. The results of an amplification of mRNA from five single cells (captured video images of 3 dissociated neurons are shown at the right side of the gel photographs), as well as positive control $(p c)$ (whole tissue from the dorsal raphe nucleus region) and negative control $(n c)$ (template for the amplification is an electrode solution from the experiment in which the electrode was submerged in the bath with isolated cells but patching was omitted), were analyzed by electrophoresis and visualized with the help of ethidium bromide staining of $2 \%$ agarose gels. $M$, Weight markers [100 bp step DNA ladder (Promega) with the $500 \mathrm{bp}$ band present at trifold intensity].

\section{The orexin-induced excitation of serotonergic neurons is occluded by activation of $\alpha_{1}$ adrenergic receptors}

The tonic firing of serotonergic neurons during waking is thought to be maintained by the activity of locus coeruleus noradrenergic neurons; noradrenaline depolarizes 5-HT neurons via activation of $\alpha_{1}$ adrenoceptors (Vandermaelen and Aghajanian, 1983; Pan et al., 1994). Two observations suggested that orexins and noradrenaline might excite serotonin neurons by similar mechanisms. First, both orexin receptors and $\alpha_{1}$ adrenoreceptors are coupled to $\mathrm{G}_{\mathrm{q}} \mathrm{G}$-proteins and activation of phospholipase C (PLC) (Ber-
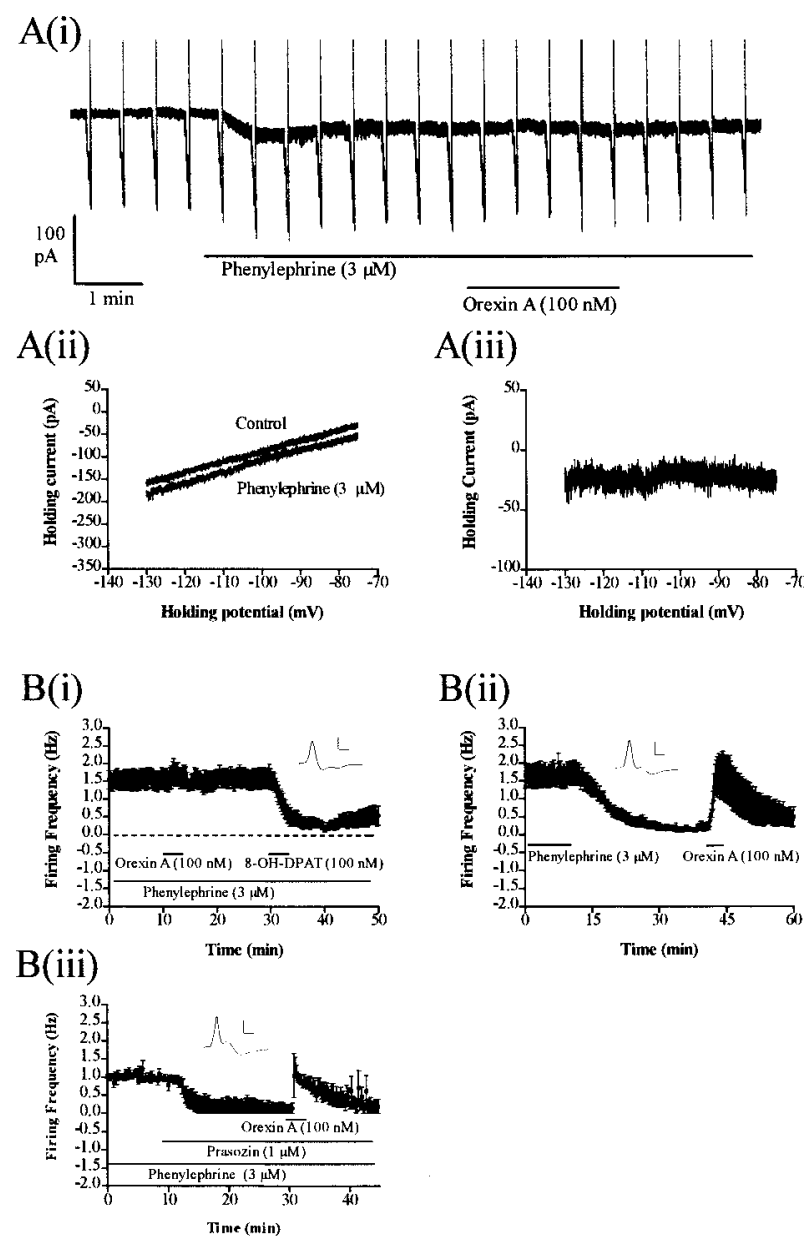

Figure 4. Activation of $\alpha_{1}$ adrenoceptors occludes the effect of orexin A. $A(i)$, Chart recording of holding current. Downward deflections represent the responses to voltage ramps from the holding potential of -75 to -130 $\mathrm{mV}$. Phenylephrine $(3 \mu \mathrm{M})$ causes an inward current and an increase in current noise. Subsequent application of orexin A (100 nM) does not lead to a further change in holding current. In $A$ (ii) the voltage ramps have been converted to a current-voltage plot. In $A$ (iii) the control current responses have been subtracted from the responses in the presence of phenylephrine. In this cell the net phenylephrine-induced current remains fairly constant over the voltage range tested. $B$, Extracellular single-unit recordings from serotonin neurons. The mean firing frequency \pm SEM is plotted against time. $B(i)$, Orexin A does not affect the firing frequency in the presence of phenylephrine $(3 \mu \mathrm{M} ; n=8)$. $B(i i)$, If phenylephrine is washed out, orexin A $(100 \mathrm{nM})$ can increase the firing frequency $(n=7)$. $B$ (iii), Orexin A (100 $\mathrm{nM})$ can also increase the firing frequency in the presence of the $\alpha_{1}$ adrenoceptor antagonist prasozin $(1 \mu \mathrm{M})$. Insets, Examples of extracellularly recorded action potentials from single experiments. Each trace is an average of 100 individual responses. Calibration: vertical, $0.5 \mathrm{mV}$; horizontal, $1 \mathrm{msec}$.

ridge, 1993; Sakurai et al., 1998). Second, the responses to orexins in current and voltage clamp that we have observed bear a strong resemblance to those described previously for $\alpha_{1}$ adrenoceptor agonists (Pan et al., 1994). We tested the idea that these two systems act via a common mechanism by performing occlusion experiments. Addition of $3 \mu \mathrm{M}$ phenylephrine to the bath caused an inward current of $-60.3 \pm 12.2 \mathrm{pA}(n=8)$ and an increase of current noise (Fig. 4A). Analysis of the current-voltage relationships revealed that the curves obtained in control and in the presence of phenylephrine did not cross; three type A responses and five type B responses were observed. Application of orexin A $(100 \mathrm{~nm})$ in the continued presence of phenylephrine did not lead 
to an additional inward current $(1.3 \pm 4.3 \mathrm{pA} ; n=6)$, even in cells such as the one illustrated in Figure 4 where phenylephrine had a relatively weak effect.

In addition to causing an inward current, noradrenaline modulates the firing of serotonin neurons by inhibition of the voltagegated potassium current, $I_{\mathrm{A}}$, and the calcium-activated potassium current responsible for the slow afterhyperpolarization (Aghajanian, 1985; Pan et al., 1994). Similarly, orexins may modulate conductances other than that responsible for the inward current. To investigate interactions between the two systems on spontaneous firing of serotonin neurons under conditions in which all mechanisms are active and the internal milieu of the neurons is undisturbed, we performed single-unit extracellular recordings in the presence of the $\alpha_{1}$ adrenoceptor agonist, phenylephrine. A concentration of phenylephrine $(3 \mu \mathrm{M})$ was chosen that elicits a rate of tonic firing similar to that seen in vivo (Vandermaelen and Aghajanian, 1983). Application of orexin A (100 nM) in the presence of phenylephrine did not increase the firing frequency of 5-HT neurons $(n=8)$ (Fig. $4 B(i))$. When phenylephrine was washed out of the slice, the firing of the cells slowly diminished and finally ceased. Application of $100 \mathrm{~nm}$ Orexin A, 30 min after washout of phenylephrine, caused the reappearance of action potentials and increased the firing rate to levels similar to those seen in the presence of phenylephrine (seven of seven cells) (Fig. $4 B(i i))$.

It has been shown previously that nicotine excites dorsal raphe neurons by depolarizing noradrenergic axons, releasing noradrenaline, which then activates $\alpha_{1}$ receptors on serotonin neurons ( $\mathrm{Li}$ et al., 1998). To determine whether this was a possible explanation for the similar responses seen with orexin and phenylephrine, we performed a further series of experiments in which the $\alpha_{1}$ adrenoceptor antagonist prasozin $(1 \mu \mathrm{M})$ was added to the perfusing solution containing phenylephrine. This led to a complete cessation of firing in three of four cells and a strong reduction in the firing rate of the other cell. Subsequent application of orexin A (100 nM) under these conditions still led to an increase in firing similar to that seen in the absence of prasozin (Fig. 4B(iii)). Thus, orexins do not act by causing the release of noradrenaline and activation of $\alpha_{1}$ adrenoceptors.

\section{Inhibitors of signal transduction do not block the effect of phenylephrine or orexin A}

Activation of receptors coupled to $\mathrm{G}_{\mathrm{q}}$-proteins leads to activation of PLC. Phospholipase C cleaves phosphatidyl-4,5-bisphosphate to generate two second messengers: diacylglycerol (DAG) and inositol 1,4,5-triphosphate $\left(\mathrm{IP}_{3}\right)$. DAG potentiates the activity of protein kinase $\mathrm{C}$, whereas $\mathrm{IP}_{3}$ causes the release of calcium from intracellular calcium stores. We investigated the role of these second messenger pathways in the effect of phenylephrine and orexin A using pharmacological tools.

In our experiments the inward current elicited by phenylephrine or orexin A was not blocked by the protein kinase $\mathrm{C}$ inhibitor chelerythrine chloride (10 $\mu \mathrm{M}$; three of three experiments each) or the inhibitor of the intracellular calcium-ATPase, thapsigargin ( $n=3$ of 3 for thapsigargin; $n=2$ of 2 for orexin A). It was also not blocked by the protein kinase A inhibitor KT5720 (1 $\mu \mathrm{M} ; n=$ 2 for phenylephrine; $n=3$ for orexin $\mathrm{A}$ ), which we have found to block the excitatory action of orexin $\mathrm{A}$ in the substantia nigra pars reticulata (Korotkova et al., 2002), or by the MAP kinase inhibitor PD98059 (5 $\mu \mathrm{M} ; n=2$ of 2 for each agonist). In contrast to the findings of Pan and colleagues (1994), we found that the inward current induced by phenylephrine $(n=2$ of 2$)$ or orexin
A $(n=2$ of 2$)$ was not blocked by the phorbol ester, phorbol 12-myristate 13 -acetate $(100 \mathrm{~nm})$, although an increase of miniature EPSCs was observed after phorbol ester application.

\section{Histamine excites serotonin neurons similarly to orexins and noradrenaline}

A third arousal-related system that innervates the dorsal raphe nucleus is the histaminergic system originating in the tuberomammillary nucleus of the hypothalamus (Panula et al., 1989). Histamine $\mathrm{H}_{1}$ receptors are the most important histamine receptors in mediating the arousing effects of histamine (Monti, 1993; Lin, 2000; Brown et al., 2001b). Like orexin receptors and $\alpha_{1}$ adrenoceptors, histamine $\mathrm{H}_{1}$ receptors are coupled to phospholipase $\mathrm{C}$ (Hill et al., 1997). Histamine (10 or $50 \mu \mathrm{M})$ depolarized serotonin neurons in current clamp (data not shown) and caused an inward current under voltage clamp (seven of seven cells) (Fig. 5A) associated with an increase in current noise. On average, $50 \mu \mathrm{M}$ histamine caused an inward current of $37.4 \pm 9.0 \mathrm{pA}(n=7)$. In six cells in which voltage ramps were applied, one type A, three type $\mathrm{B}$, and two type $\mathrm{C}$ responses were observed.

Occlusion experiments with phenylephrine were performed using single-unit recordings. Application of histamine $(50 \mu \mathrm{M})$ in the presence of $3 \mu \mathrm{M}$ phenylephrine did not lead to an increase in the firing rate of serotonin neurons (Fig. 5B(i)) (six of six), whereas in experiments in which phenylephrine was washed out, histamine $(50 \mu \mathrm{M})$ increased the firing rate to a similar level as seen in the presence of phenylephrine in four of six cases (Fig. $5 B(i i))$. The effect of histamine was not dependent on the release of noradrenaline and subsequent activation of $\alpha_{1}$ adrenoceptors, because histamine $(50 \mu \mathrm{M})$ increased the spontaneous firing rate in the presence of the $\alpha_{1}$ adrenoceptor antagonist prasozin $(1 \mu \mathrm{M})$ in four of seven cases (Fig. 5B(iii)). In the continued presence of histamine in the bath, the firing rate remained steady. Subsequent application of the histamine $\mathrm{H}_{1}$ receptor antagonist, mepyramine $(1 \mu \mathrm{M})$, strongly depressed the firing rate $(n=4)$ (Fig. $5 B(i i i))$, indicating that histamine $\mathrm{H}_{1}$ receptors are responsible for the histamine effect.

\section{The excitation of serotonin neurons by orexin A and phenylephrine is dependent on external sodium}

The fact that the current-voltage curves for orexins, phenylephrine, and histamine did not cross at the potassium equilibrium potential indicated that the blockade of leak potassium channels could not (on its own) account for the inward current/depolarization. We tested for the involvement of sodium ions in the orexin A-induced current by replacing $124 \mathrm{~mm}$ of the external sodium ions with NMDG. Under these conditions, the orexin A-induced inward current and increase in current noise were strongly attenuated $(-10.7 \pm 3.9 \mathrm{pA} ; n=7)$ (Fig. $6 A)$. In experiments in which only $15 \mathrm{~mm}$ of the external $\mathrm{NaCl}$ was replaced by NMDG.Cl, an inward current could still be observed in four of five cases, the magnitude of which $(-31.1 \pm 7.8 \mathrm{pA} ; n=$ 4) was not significantly different from control. Thus, it is unlikely that the effect of $124 \mathrm{~mm}$ NMDG was attributable to a direct blocking effect on the channels but rather was caused by substitution of the external sodium. Similar to orexin A, in $124 \mathrm{~mm}$ NMDG, the inward currents induced by $3 \mu \mathrm{M}$ phenylephrine $(-16.5 \pm 5.6 \mathrm{pA} ; n=7)$ and $50 \mu \mathrm{M}$ histamine $(-12.7 \pm 3.7 \mathrm{pA}$; $n=6)$ were significantly $(p<0.05)$ reduced in comparison with the currents recorded in control solution.

The increase in current noise and the dependence on external sodium suggested that a sodium-permeable ion channel mediates 


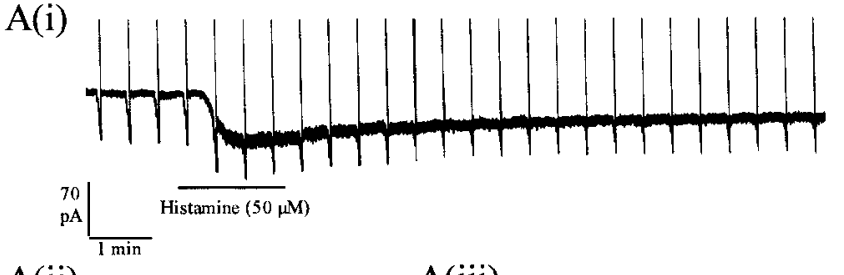

A(ii)


B(ii)
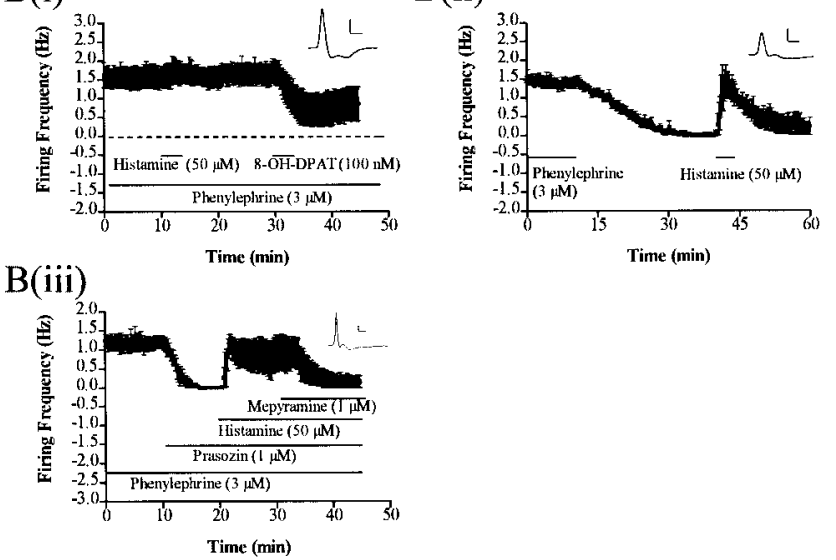

Figure 5. Histamine excites serotonin neurons. $A(i)$, Chart recording of holding current. Downward deflections represent the responses to voltage ramps from the holding potential of -75 to $-130 \mathrm{mV}$. Histamine $(50 \mu \mathrm{M})$ causes an inward current and an increase in current noise. In $A$ (ii) the voltage ramps have been converted to a current-voltage plot. In $A$ (iii) the control current responses have been subtracted from the responses in the presence of histamine. In this cell the net histamine-induced current declines in amplitude in the hyperpolarizing direction. $B$, Extracellular single-unit recordings from serotonin neurons. The mean firing frequency \pm SEM is plotted against time. $B(i)$, Histamine $(50 \mu \mathrm{M})$ does not affect the firing frequency in the presence of phenylephrine $(3 \mu \mathrm{M} ; n=6)$. $B$ (ii), If phenylephrine is washed out, histamine $(50 \mu \mathrm{M})$ can increase the firing frequency (in 4 of 6 cases). B(iii), Histamine $(50 \mu \mathrm{M})$ can also increase the firing frequency in the presence of the $\alpha_{1}$ adrenoceptor antagonist, prasozin ( $1 \mu \mathrm{M} ; 4$ of 7 cases). Furthermore, this effect is blocked by the histamine $\mathrm{H}_{1}$ receptor antagonist, mepyramine $(1 \mu \mathrm{M})$. Insets, Examples of extracellularly recorded action potentials from single experiments. Each trace is an average of 100 individual responses. Calibration: vertical, $0.5 \mathrm{mV}$; horizontal, $1 \mathrm{msec}$.

the inward current, either alone or with concurrent blockade of leak potassium channels (Pan et al., 1994). We attempted to determine the reversal potential of this putative sodiumpermeable ion channel by applying voltage ramps from -100 to $+20 \mathrm{mV}$ in the presence of potassium channel blockers (either 2 $\mathrm{mm}$ external barium or using an intracellular $\mathrm{CsCl}$-based patch solution). Barium (2 mM) did not block the effect of orexin A (100 $\mathrm{nM} ;-37.2 \pm 7.6 ; n=5)$ or phenylephrine $(3 \mu \mathrm{M} ;-37.0 \pm 3.6 \mathrm{pA}$; $n=5)$. However, these ramps were disturbed by calcium spikes, which appeared around $-30 \mathrm{mV}$. Addition of $2 \mathrm{mM} \mathrm{NiCl}_{2}$ or 100 $\mu \mathrm{M} \mathrm{CdCl} l_{2}$ to the bathing solution blocked the calcium spikes but also reduced the effect of orexin A or phenylephrine $(n=5)$. In
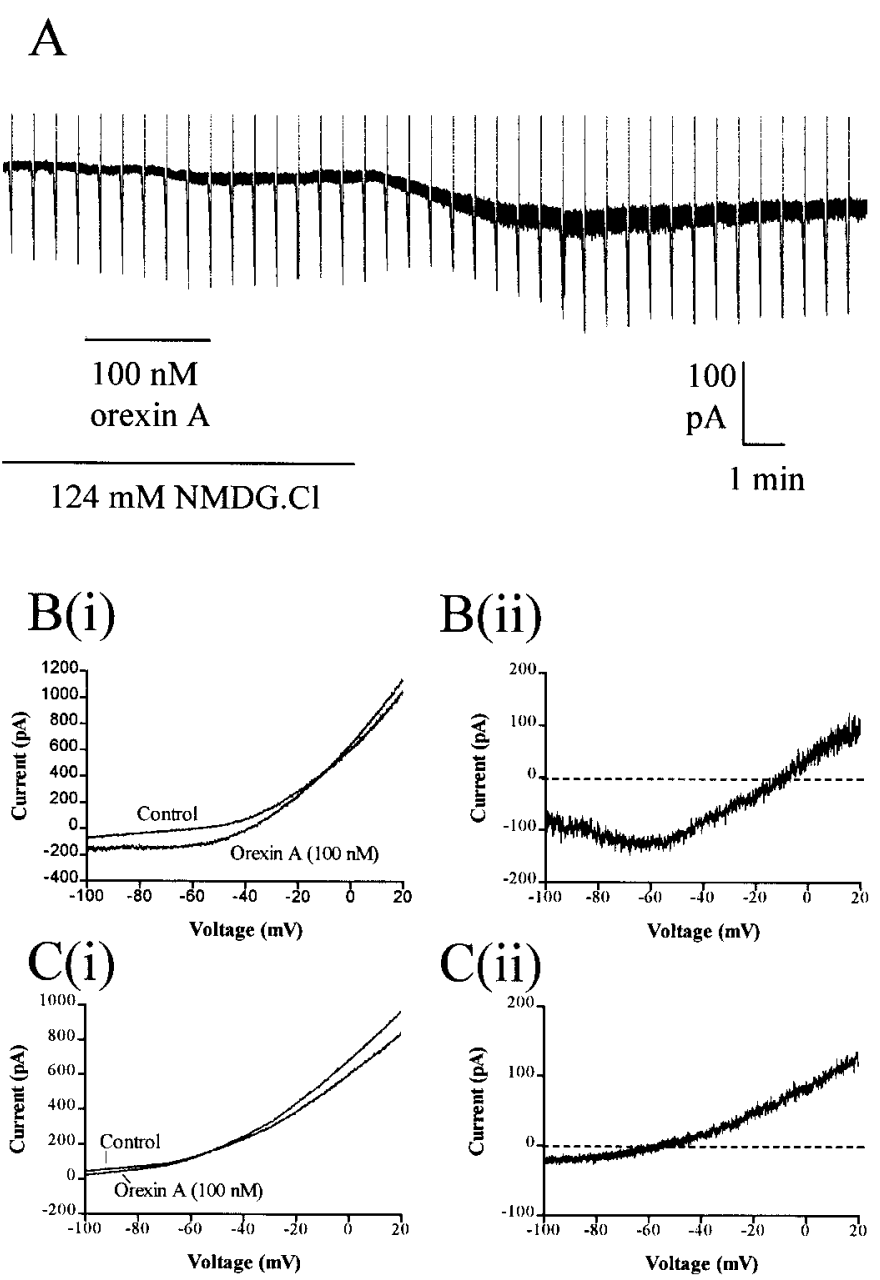

Figure 6. Involvement of a nonselective cation channel in the effect of orexin A. A, Chart recording of membrane potential. Downward deflections represent voltage ramps from -75 to $-130 \mathrm{mV}$. When orexin $\mathrm{A}$ is applied in an extracellular solution in which $124 \mathrm{~mm}$ of $\mathrm{NaCl}$ has been replaced by $\mathrm{N}$-methyl-D-glucamine chloride (NMDG.Cl), only a small inward current and increase in current noise are observed. When NMDG-containing solution is replaced by normal extracellular solution during the period when the orexin A effect is normally still active, a larger inward current and increase in noise slowly appear. $B(i)$, In one experiment performed in extracellular solution containing $0 \mathrm{Ca}^{2+} / 3.3 \mathrm{Mg}^{2+}$, slow $(20 \mathrm{sec})$ voltage ramps from -100 to $+20 \mathrm{mV}$ in control and in the presence of orexin A cross at $-10 \mathrm{mV}$. B(ii), The control curve has been subtracted from the response obtained in the presence of orexin A to give the orexin A-induced current. $C(i)$, In one experiment performed in extracellular solution containing $124 \mathrm{mM} \mathrm{NMDG}^{+} / 25.6 \mathrm{mM} \mathrm{Na}^{+} / 0 \mathrm{Ca}^{2+} /$ $3.3 \mathrm{Mg}^{2+}$, slow $(20 \mathrm{sec})$ voltage ramps from -100 to $+20 \mathrm{mV}$ in control and in the presence of orexin A cross at $-55 \mathrm{mV}$. C(ii), The control curve has been subtracted from the response obtained in the presence of orexin A to give the orexin A-induced current.

contrast, application of $\mathrm{NiCl}_{2}$ or $\mathrm{CdCl}_{2}$ after the inward current had already been induced did not reverse the effect $(n=3)$.

Because it was not possible to use $\mathrm{Cd}$ or $\mathrm{Ni}$, we conducted experiments in calcium-free solution. The concentration of magnesium was increased to $3.3 \mathrm{~mm}$ to preserve the concentration of divalent cations. Under these conditions the orexin A-induced current was not blocked $(-61.4 \pm 12.8 \mathrm{pA} ; n=9)$ so we were able to apply long voltage ramps $(-100$ to $+20 \mathrm{mV})$ without contamination with calcium spikes. Despite a slow rundown of outward currents in the range -30 to $+20 \mathrm{mV}$, in five of nine experiments, the orexin-induced current reversed at $-23 \pm 7 \mathrm{mV}$ (Fig. $6 B$ ). In 
the remaining four experiments the curves converged and came very close to each other in the range -30 to $0 \mathrm{mV}$ but then diverged again at positive potentials. In the range -100 to -30 $\mathrm{mV}$, the orexin A-induced current decreased linearly in four cases (type $\mathrm{C}$ response). In four cases the current was voltage independent between -100 and $-70 \mathrm{mV}$ and then decreased linearly (type $\mathrm{B}$ response). In the final case (type A response; illustrated in Fig. $6 B$ ), there was a region of negative slope conductance between -100 and $-60 \mathrm{mV}$, a maximum at $-60 \mathrm{mV}$, and a decrease of the current between -60 and $-10 \mathrm{mV}$ (where it reversed).

The value that we obtained for the reversal potential of these channels $(-23 \mathrm{mV})$ is far from the reversal potential for sodium, so a pure sodium conductance is unlikely to account for our results. We calculated the relative permeability of sodium to potassium $(\mathrm{pNa} / \mathrm{pK})$ by inserting the experimentally obtained reversal potentials and the concentrations of sodium and potassium into the Goldmann-Hodgkin-Katz equation. This gave a $\mathrm{pNa} / \mathrm{pK}$ of $0.43 \pm 0.1(n=5)$. In calcium-free extracellular solution containing reduced sodium (124 mM $\mathrm{NMDG}^{+} / 25.6 \mathrm{~mm}$ $\mathrm{Na}^{+} / 0 \mathrm{Ca}^{2+} / 3.3 \mathrm{Mg}^{2+}$ ), the reversal potential for sodium is $+25.9 \mathrm{mV}$, and the predicted reversal potential for a cationic current with the relative permeabilities calculated above is $-64 \pm$ $5 \mathrm{mV}(n=5)$. Reversal of the current was seen in six of nine experiments in this solution. The reversal potential $(-49 \pm 6 \mathrm{mV}$; $n=6$ ) (Fig. 6C) was not significantly different from the predicted value but was significantly $(p<0.05)$ more negative than the value obtained in solution containing the normal extracellular sodium concentration. The current did not reverse in the remaining three experiments.

It should be noted that the calculated reversal potentials are based on a voltage-insensitive nonselective cation current; however, at least some of the conductances of the responses that we obtained were clearly voltage sensitive (type A responses). In addition, the reversal potential measurements are likely to suffer from voltage-clamp and space-clamp errors caused by the use of the single-electrode voltage-clamp technique and recordings from neurons with elongated dendrites, which are unlikely to have been adequately clamped. Thus, these values can only be considered a first approximation.

\section{DISCUSSION}

We have shown here that three different arousal systems, the orexin, histamine, and noradrenaline systems, excite dorsal raphe serotonergic neurons. These systems act through postsynaptically located $\mathrm{OX}_{1}, \mathrm{OX}_{2}, \mathrm{H}_{1}$, and $\alpha_{1}$ receptors, respectively.

Previous studies have demonstrated the presence of orexin fibers in the dorsal raphe nucleus (Peyron et al., 1998; Chemelli et al., 1999). We found that both orexin A and orexin B excited 5-HT neurons, whereas $\mathrm{MCH}$, which is located in neurons intermingled with orexin neurons in the lateral hypothalamic area (Bittencourt et al., 1992), was without effect. Orexin A has high (nanomolar) affinity for both orexin receptors, whereas orexin B has high affinity for the type II orexin receptor $\left(\mathrm{OX}_{2}\right)$ and only low (micromolar) affinity for the type I receptor (Sakurai et al., 1998). In our study, the potency of orexin A and orexin B tested at $100 \mathrm{~nm}$ was very similar in current-clamp and voltage-clamp experiments, and the $\mathrm{EC}_{50}$ for orexin $\mathrm{B}$ in voltage-clamp experiments $(22 \mathrm{nM})$ was in the range expected for an effect mediated by $\mathrm{OX}_{2}$ receptors (Sakurai et al., 1998). Occasional cells did not respond to orexin $\mathrm{B}$ but did subsequently respond to orexin $\mathrm{A}$ or the $\alpha_{1}$ receptor agonist, phenylephrine. Furthermore, in single- cell PCR experiments we found that all tryptophan hydroxylasepositive cells had a strong signal for $\mathrm{OX}_{1}$, whereas the signal for $\mathrm{OX}_{2}$ was more variable, and in some cells no signal could be detected. Taken together, these results suggest that most of the 5-HT cells in the dorsal raphe contain both types of orexin receptors, whereas some cells contain only $\mathrm{OX}_{1}$ receptors. This conclusion is in accordance with the findings using in situ hybridization, which demonstrated the presence of mRNA for both receptor types in the dorsal raphe (Trivedi et al., 1998; Marcus et al., 2001), and with the presence of the orexin 1 receptor protein, as shown by immunohistochemistry (Hervieu et al., 2001).

The similarities between the effects of orexins and phenylephrine on dorsal raphe neurons (see below), together with the fact that orexin receptors, like $\alpha_{1}$ adrenoceptors, are coupled to phospholipase C (Sakurai et al., 1998), led us to perform occlusion experiments and also to test a further arousal-related system, the histamine system, the $\mathrm{H}_{1}$ receptors of which are also coupled to this signal transduction cascade (Hill et al., 1997). The presence of $\mathrm{H}_{1}$ receptors in the dorsal raphe has been demonstrated previously in the guinea pig (Bouthenet et al., 1988), and here we found in extracellular recordings that the effect of histamine on serotonin neurons was blocked by the $\mathrm{H}_{1}$ receptor antagonist, mepyramine.

Several lines of evidence suggest that the three systems act on common effector mechanisms. First, orexin A, phenylephrine, and histamine all induced an inward current in voltage-clamp recordings that was associated with a prominent increase in current noise. Second, the current-voltage relationships for all three agonists in the range -130 to $-75 \mathrm{mV}$ were similar. Third, the inward current for all three agonists was significantly reduced in extracellular solution in which most of the sodium had been replaced by the impermeant ion NMDG. Finally, the inward current caused by orexin A and the excitatory effects of orexin A and histamine in extracellular recordings were occluded by previous activation of $\alpha_{1}$ receptors.

Both orexin receptors, $\alpha_{1}$ adrenoceptors, and histamine $\mathrm{H}_{1}$ receptors all normally couple to $\mathrm{G}_{\mathrm{q}} \mathrm{G}$-proteins and to phospholipase C (Hill et al., 1997; Sakurai et al., 1998). However, in our experiments, the inward current induced by orexin A or phenylephrine was not blocked by inhibitors of the two major phospholipase $\mathrm{C}$ signaling pathways: release of calcium from $\mathrm{IP}_{3}$-sensitive stores and activation of protein kinase C. Further experiments will be required to determine whether the coupling between receptors and effectors is mediated directly, through G-proteins alone, or through so far unidentified second messengers.

In current-clamp experiments, orexins on average increased the input resistance measured by application of hyperpolarizing pulses. This suggested that a blockade of leak potassium conductance was responsible for the excitation (Brown et al., 2001a). However, closer examination of the data revealed that in individual experiments, this increase was extremely variable and not correlated with the amplitude of the depolarization. In voltageclamp experiments, voltage ramps did not cross at the potassium equilibrium potential. Furthermore, the observed inward current was accompanied by a large increase in current noise, suggesting that channels were in fact being opened by orexins. These findings were reminiscent of those found by Pan and colleagues (1994) in their investigation of $\alpha_{1}$ adrenoceptor effects on serotonin neurons. These authors found that the inward current caused by phenylephrine did not reverse in sharp-electrode recordings or in whole-cell recordings when the drug was tested shortly after the whole-cell configuration was obtained. However, in many cells 
they found that if they waited 15-20 min after obtaining the whole-cell configuration, then phenylephrine caused an inward current that did cross at the potassium equilibrium potential, indicating that modulation of a potassium channel is a component of the response. In the remainder of the cells, the $I-V$ curves did not cross, similar to the results that we present here. In contrast to Pan and colleagues (1994), in our experiments we discarded neurons that did not have a stable holding current, and the effects of phenylephrine, orexin, or histamine were usually tested within 20 min of obtaining whole-cell access.

Our experiments suggest that activation of a mixed cation channel is an important component of the action of orexins, histamine, and noradrenaline. The effects of orexin A, phenylephrine, and histamine were strongly reduced by replacement of $124 \mathrm{~mm}$ of the external sodium by the impermeant ion NMDG. This is similar to results in the tuberomammillary neurons, where we concluded that a sodium-calcium exchanger mediates the effect of orexins (Eriksson et al., 2001); however, here the inward currents were always associated with a prominent increase in current noise that was generated by the stochastic opening of ion channels. In just over half the recordings in calcium-free solution, current-voltage plots were found to cross at $-23 \mathrm{mV}$, which is consistent with relative permeabilities for sodium and potassium of 0.43 and 1 , respectively. Furthermore, the reversal potential was significantly shifted in the hyperpolarizing direction in calcium-free extracellular solution containing low sodium.

Recently a family of nonselective cation channels, which are activated by receptors that can couple to phospholipase $\mathrm{C}$ and generate "noisy" currents, have been identified in invertebrates and mammalian tissues (the transient receptor potential channels) (Harteneck et al., 2000). In preliminary single-cell PCR experiments, we have found that tryptophan hydroxylase-positive neurons from the dorsal raphe region express several members of this family of channels (O. Sergeeva, unpublished observations).

In some experiments we were unable to obtain a clear reversal of the current. This could be explained by a contribution caused by the blockade of leak potassium channels, as described by Pan and colleagues (1994). As the holding potential becomes more positive, this contribution would become larger, whereas the contribution of the nonselective cation current becomes smaller (or reverses). Alternatively, the failure to observe reversal may have been caused by the rundown of outward currents.

The convergence of multiple arousal systems on common effector systems seen here is reminiscent of the convergence of these systems on thalamic relay cells and cortical pyramidal neurons (McCormick, 1992) and emphasizes once again the importance of the serotonin system during waking. A further implication of these findings is that if the effector mechanisms are fully activated by one of the systems, then the other systems will be without effect on the firing of serotonin neurons. This does not appear to be the case, because intracerebroventricular administration of orexin A leads to a grooming response that can be blocked by antagonists of 5- $\mathrm{HT}_{2 \mathrm{C}}$ receptors (Duxon et al., 2001).

The orexin system has aroused considerable interest in the last few years because of its involvement in the sleep disorder, narcolepsy, which involves a dysregulation in the timing of REM sleep episodes (Nishino and Mignot, 1997; Chemelli et al., 1999; Lin et al., 1999; Thannickal et al., 2000; Hara et al., 2001). In particular, the orexin type II receptor, which we have shown here to be involved in the effects of orexins on raphe neurons, is of importance. Canines or mice lacking the type II receptor are narcoleptic, whereas mice lacking only the type I receptors are not (Lin et al., 1999; Willie et al., 2001). Serotonin systems play an important role in suppression of REM sleep, in particular the rapid eye movements and pontine-geniculate-occipital spikes that accompany dreaming (Hobson et al., 1975; Lydic et al., 1987). Lack of orexin modulation of dorsal raphe neurons in narcolepsy would not be critical if noradrenergic and histaminergic inputs could compensate, but unfortunately these two systems are also normally excited by orexins (Hagan et al., 1999; Eriksson et al., 2002), and thus their input to serotonin neurons is also likely to be weakened. The weakened input from these systems to dorsal raphe serotonin neurons in narcolepsy is likely to be important in several aspects of the disease, including sleep-onset REM periods and sleep-associated hallucinations.

\section{REFERENCES}

Aghajanian GK (1985) Modulation of a transient outward current in serotonergic neurones by alpha 1-adrenoceptors. Nature 315:501-503.

Aghajanian GK, Lakoski JM (1984) Hyperpolarization of serotonergic neurons by serotonin and LSD: studies in brain slices showing increased $\mathrm{K}^{+}$conductance. Brain Res 305:181-185.

Aghajanian GK, Rasmussen K (1989) Intracellular studies in the facial nucleus illustrating a simple new method for obtaining viable motoneurons in adult rat brain slices. Synapse 3:331-338.

Aston-Jones G, Bloom FE (1981) Activity of norepinephrine-containing locus coeruleus neurons in behaving rats anticipates fluctuations in the sleep-waking cycle. J Neurosci 1:876-886.

Baraban JM, Aghajanian GK (1980) Suppression of firing activity of 5 -HT neurons in the dorsal raphe by alpha-adrenoceptor antagonists. Neuropharmacology 19:355-363.

Berridge MJ (1993) Inositol triphosphate and calcium signaling. Nature 361:315-325

Bittencourt JC, Presse F, Arias C, Peto C, Vaughan J, Nahon JL, Vale W, Sawchenko PE (1992) The melanin-concentrating hormone system of the rat brain: an immuno- and hybridization histochemical characterization. J Comp Neurol 319:218-245.

Bouthenet ML, Ruat M, Sales N, Garbarg M, Schwartz JC (1988) A detailed mapping of histamine H1-receptors in guinea-pig central nervous system established by autoradiography with $\left[{ }^{125} \mathrm{I}\right]$ iodobolpyramine. Neuroscience 26:553-600.

Brown RE, Sergeeva OA, Eriksson KS, Haas HL (2001a) Orexin A excites serotonergic neurons in the dorsal raphe nucleus of the rat. Neuropharmacology 40:457-459.

Brown RE, Stevens DR, Haas HL (2001b) The physiology of brain histamine. Prog Neurobiol 63:637-672.

Chemelli RM, Willie JT, Sinton CM, Elmquist JK, Scammell T, Lee C, Richardson JA, Williams SC, Xiong Y, Kisanuki Y, Fitch TE, Nakazato M, Hammer RE, Saper CB, Yanagisawa M (1999) Narcolepsy in orexin knockout mice: molecular genetics of sleep regulation. Cell 98:437-451.

Date Y, Ueta Y, Yamashita H, Yamaguchi H, Matsukura S, Kangawa K, Sakurai T, Yanagisawa M, Nakazato M (1999) Orexins, orexigenic hypothalamic peptides, interact with autonomic, neuroendocrine and neuroregulatory systems. Proc Natl Acad Sci USA 96:748-753.

Dringenberg HC, Vanderwolf CH (1998) Involvement of direct and indirect pathways in electrocorticographic activation. Neurosci Biobehav Rev 22:243-257.

Duxon MS, Stretton J, Starr K, Jones DN, Holland V, Riley G, Jerman J, Brough S, Smart D, Johns A, Chan W, Porter RA, Upton N (2001) Evidence that orexin-A-evoked grooming in the rat is mediated by orexin- 1 (OX1) receptors, with downstream 5-HT2C receptor involvement. Psychopharmacology (Berl) 153:203-209.

Eriksson KS, Sergeeva OA, Brown RE, Haas HL (2001) Orexin/hypocretin excites the histaminergic neurons of the tuberomammillary nucleus. J Neurosci 21:9273-9279.

Estabrooke IV, McCarthy MT, Ko E, Chou TC, Chemelli RM, Yanagisawa M, Saper CB, Scammell TE (2001) Fos expression in orexin neurons varies with behavioral state. J Neurosci 21:1656-1662.

Hagan JJ, Leslie RA, Patel S, Evans ML, Wattam TA, Holmes S, Benham CD, Taylor SG, Routledge C, Hemmati P, Munton RP, Ashmeade TE, Shah AS, Hatcher JP, Hatcher PD, Jones DN, Smith MI, Piper DC, Hunter AJ, Porter RA, Upton N (1999) Orexin A activates locus coeruleus cell firing and increases arousal in the rat. Proc Natl Acad Sci USA 96:10911-10916.

Hara J, Beuckmann CT, Nambu T, Willie JT, Chemelli RM, Sinton CM, Sugiyama F, Yagami K, Goto K, Yanagisawa M, Sakurai T (2001) Genetic ablation of orexin neurons in mice results in narcolepsy, hypophagia, and obesity. Neuron 30:345-354.

Harteneck C, Plant TD, Schultz G (2000) From worm to man: three subfamilies of TRP channels. Trends Neurosci 23:159-166. 
Hervieu GJ, Cluderay JE, Harrison DC, Roberts JC, Leslie RA (2001) Gene expression and protein distribution of the orexin-1 receptor in the rat brain and spinal cord. Neuroscience 103:777-797.

Hill SJ, Ganellin CR, Timmerman H, Schwartz JC, Shankley NP, Young JM, Schunack W, Levi R, Haas HL (1997) International Union of Pharmacology. XIII. Classification of histamine receptors. Pharmacol Rev 49:253-278.

Hobson JA, McCarley RW, Wyzinski PW (1975) Sleep cycle oscillation: reciprocal discharge by two brainstem neuronal groups. Science 189:55-58

Jacobs BL, Azmitia EC (1992) Structure and function of the brain serotonin system. Physiol Rev 72:165-229.

Jacobs BL, Fornal CA (1991) Activity of brain serotonergic neurons in the behaving animal. Pharmacol Rev 43:563-578.

Kilduff TS, Peyron C (2000) The hypocretin/orexin ligand-receptor system: implications for sleep and sleep disorders. Trends Neurosci 23:359-365

Korotkova TM, Eriksson KS, Haas HL, Brown RE (2002) Selective excitation of GABAergic neurons in the substantia nigra of the rat by orexin/hypocretin in vitro. Regul Peptides 104:83-89.

Kruger L, Saporta S, Swanson L (1995) Photographic atlas of the rat brain. Cambridge, UK: Cambridge UP.

Li X, Rainnie DG, McCarley RW, Greene RW (1998) Presynaptic nicotinic receptors facilitate monoaminergic transmission. J Neurosci 18:1904-1912.

Lin JS (2000) Brain structures and mechanisms involved in the control of cortical activation and wakefulness, with emphasis on the posterior hypothalamus and histaminergic neurons. Sleep Med Rev 4:471-503.

Lin L, Faraco J, Li R, Kadotani H, Rogers W, Lin X, Qiu X, de Jung PJ, Nishino S, Mignot E (1999) The sleep disorder canine narcolepsy is caused by a mutation in the hypocretin (orexin) receptor 2 gene. Cell 98:365-376.

Lucki I (1998) The spectrum of behaviors influenced by serotonin. Biol Psychiatry 44:151-162.

Lydic R, McCarley RW, Hobson JA (1987) Serotonin neurons and sleep. II. Time course of dorsal raphe discharge, PGO waves, and behavioral states. Arch Ital Biol 126:1-28.

Marcus JN, Aschkenasi CJ, Lee CE, Chemelli RM, Saper CB, Yanagisawa M, Elmquist JK (2001) Differential expression of orexin receptors 1 and 2 in the rat brain. J Comp Neurol 435:6-25.

McCormick DA (1992) Neurotransmitter actions in the thalamus and cerebral cortex and their role in neuromodulation of thalamocortical activity. Prog Neurobiol 39:337-388.

Monti JM (1993) Involvement of histamine in the control of the waking state. Life Sci 53:1331-1338.

Nishino S, Mignot E (1997) Pharmacological aspects of human and canine narcolepsy. Prog Neurobiol 52:27-78.

Pan ZZ, Grudt TJ, Williams JT (1994) Alpha 1-adrenoceptors in rat dorsal raphe neurons: regulation of two potassium conductances. J Physiol (Lond) 478:437-447.
Panula P, Pirvola U, Auvinen S, Airaksinen MS (1989) Histamineimmunoreactive nerve fibres in the rat brain. Neuroscience 28:585-610.

Penington NJ, Kelly JS, Fox AP (1993) Whole-cell recordings of inwardly rectifying $\mathrm{K}^{+}$currents activated by 5-HT1A receptors on dorsal raphe neurones of the adult rat. J Physiol (Lond) 469:387-405.

Peyron C, Tighe DK, van den Pol AN, de Lecea L, Heller HC, Sutcliffe JG, Kilduff TS (1998) Neurons containing hypocretin (orexin) project to multiple neuronal systems. J Neurosci 18:9996-10015.

Piper DC, Upton N, Smith MI, Hunter AJ (2000) The novel brain neuropeptide, orexin-A, modulates the sleep-wake cycle of rats. Eur J Neurosci 12:726-730.

Sakai K, Crochet S (2001) Differentiation of presumed serotonergic dorsal raphe neurons in relation to behavior and wake-sleep states. Neuroscience 104:1141-1155.

Sakai K, El Mansari M, Lin JS, Zhang JG, Vanni Mercier G (1990) The posterior hypothalamus in the regulation of wakefulness and paradoxical sleep. In: The diencephalon and sleep (Mancia M, Marini G, eds), pp 171-198. New York: Raven.

Sakurai T, Amemiya A, Ishii M, Matsuzaki I, Chemelli RM, Tanaka H, Williams SC, Richarson JA, Kozlowski GP, Wilson S, Arch JR, Buckingham RE, Haynes AC, Carr SA, Annan RS, McNulty DE, Liu WS, Terrett JA, Elshourbagy NA, Bergsma DJ, Yanagisawa M (1998) Orexins and orexin receptors: a family of hypothalamic neuropeptides and $\mathrm{G}$ protein-coupled receptors that regulate feeding behavior. Cell 92:573-585.

Staley KJ, Otis TS, Mody I (1992) Membrane properties of dentate gyrus granule cells: comparison of sharp microelectrode and whole-cell recordings. J Neurophysiol 67:1346-1358.

Taheri S, Sunter D, Dakin C, Moyes S, Seal L, Gardiner J, Rossi M, Ghatei M, Bloom S (2000) Diurnal variation in orexin A immunoreactivity and prepro-orexin mRNA in the rat central nervous system. Neurosci Lett 279:109-112.

Thannickal TC, Moore RY, Nienhuis R, Ramanathan L, Gulyani S, Aldrich M, Cornford M, Siegel JM (2000) Reduced number of hypocretin neurons in human narcolepsy. Neuron 27:469-474.

Trivedi P, Yu H, MacNeil DJ, Van der Ploeg LH, Guan XM (1998) Distribution of orexin receptor mRNA in the rat brain. FEBS Lett 438:71-75.

Trulson ME, Jacobs BL (1979) Raphe unit activity in freely moving cats: correlation with level of behavioral arousal. Brain Res 163:135-150.

Vandermaelen CP, Aghajanian GK (1983) Electrophysiological and pharmacological characterization of serotonergic dorsal raphe neurons recorded extracellularly and intracellularly in rat brain slices. Brain Res 289:109-119.

Vorobjev VS, Sharonova IN, Haas HL, Sergeeva OA (2000) Differential modulation of AMPA receptors by cyclothiazide in two types of striatal neurons. Eur J Neurosci 12:2871-2880.

Willie JT, Chemelli RM, Sinton CM, Yanagisawa M (2001) To eat or to sleep? Orexin in the regulation of feeding and wakefulness. Annu Rev Neurosci 24:429-458. 